\title{
Religion as force for good
}

ECUMENICAL PATRIARCH BARTHOLOMEW

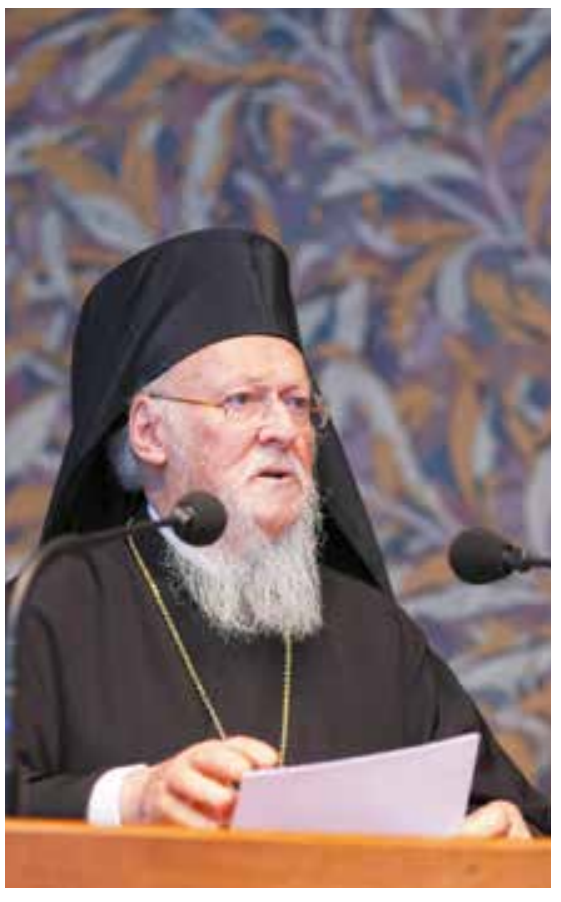

In our humble opinion, disputing the role of religion in the contemporary world is a thing of the past. It reflects an old-fashioned ideology, which no longer corresponds not only to the essential demands of society, but also to the evident crucial functions of religion both on the personal and the social level. It would be an unfortunate loss for the democratic political system today if religion were ignored. The truth is that neither religious principles nor secular values exist in isolation, but both flourish in creative and constructive dialogue.

We are convinced that it is an inaccurate attitude that religion somehow hampers or menaces progress or nourishes only fundamentalism and division. Nevertheless, this mindset creates a moral vacuum in a society that is shaped solely by economic factors in a globalised world. Religion, however, must neither choose, nor be compelled to retreat from the public space. It must be invited to address social and political issues, to respond to the challenge of human suffering and environmental degradation, and to become involved in sensitive discussions about human rights and against intolerance.

In this perspective, the world of faith can be a powerful ally for engaging in issues of social justice. Arguably, religion can function as one of the most persuasive and transformative forces on earth. Its unique vantage point can contribute today to a more 'human' globalisation, as well as advocating for peace and solidarity 
and against racism and discrimination, while at the same time championing religious tolerance and human dignity. Very rarely is religion not a defining element of the identity and integrity of a community. This is why religion is the subject of renewed interest and attention in international relations and global politics, directly impacting social values and indirectly influencing state policies. Whether dealing with the environment or peace, poverty or hunger, education or healthcare, there is today an increasing sense of common concern and common responsibility. Indeed, any analysis of our contemporary cultural setting would be incomplete without taking into consideration the presence and impact of religion.

The issues that our world faces are in some ways hardly new. History is replete with examples of violence, cruelty, and atrocities, committed by one group of people against another. However, our present situation is, in at least two ways, quite unprecedented. First, never before has it been possible for one group of human beings to eradicate as many people simultaneously; second, never before has humanity been in a position to destroy so much of the planet environmentally. This predicament presents us with totally new circumstances, which demand of us a radical commitment to reconciliation and peace. The threat to the fabric of human life and the survival of the natural environment make this the overarching priority over all others.

Therefore, as faith communities and religious leaders, it is our vocation and obligation to pursue and proclaim alternative ways to manage human affairs, ways that reject war and violence, and instead recognise and strive for justice and peace. Conflict may be inevitable in our world; but war and violence are certainly not. National tensions may be unavoidable across borders; but tolerance and peaceful coexistence are a categorical imperative. Compassion and change through religion can break the cycle of violence and injustice. In the final analysis, making peace is a matter of individual and institutional choice, as well as of individual and institutional transformation.

Building bridges through encounter and dialogue is a universal human principle. It is also a fundamental Christian mandate, as well as a quintessential part of the DNA of the Ecumenical Patriarchate in its mission to the contemporary world. The Ecumenical Patriarchate has always been convinced of its wider role in the world and of its ecumenical responsibility. Since 1977, we have initiated bilateral interfaith dialogue with the Jewish faith; and since 1986, we have convened several high-level encounters with the Islamic community on such topics as authority and justice, pluralism and coexistence, war and peace, as well as religious tolerance and religious rights. All of these conversations and 

Permit us to conclude with a biblical image that underlines the importance of encounter and dialogue in society. Sitting under the shade of the oak trees in Palestine, Abraham received an unexpected visit from three strangers. It is a story recorded in the Book of Genesis, chapter I8. In this biblical narrative, it is refreshing to observe that Abraham does not consider his foreign visitors as posing any danger or threat to his lifestyle or property. Instead, he spontaneously and openly shares with them his friendship and his food, his relationship and his resources. In fact, he extends such gracious and generous hospitality that, in the Orthodox Church, this scene is interpreted and identified as the revelation of God himself.

In images that depict this scene, there is always an empty seat at the table where Abraham is feeding his unknown guests. The question that we leave you with is this: How many foreigners are we willing to seat at our table? We must ask ourselves how many difficult issues are we willing to address together as a society? We must question whether we are willing to open our communities and our hearts to share with foreigners and refugees. And, if we honestly want to effect change - in ourselves and in our world - then we commit to working together and no longer in isolation. The future does not belong to the homo clausus, the 'enclosed man', because he does not care for the future.

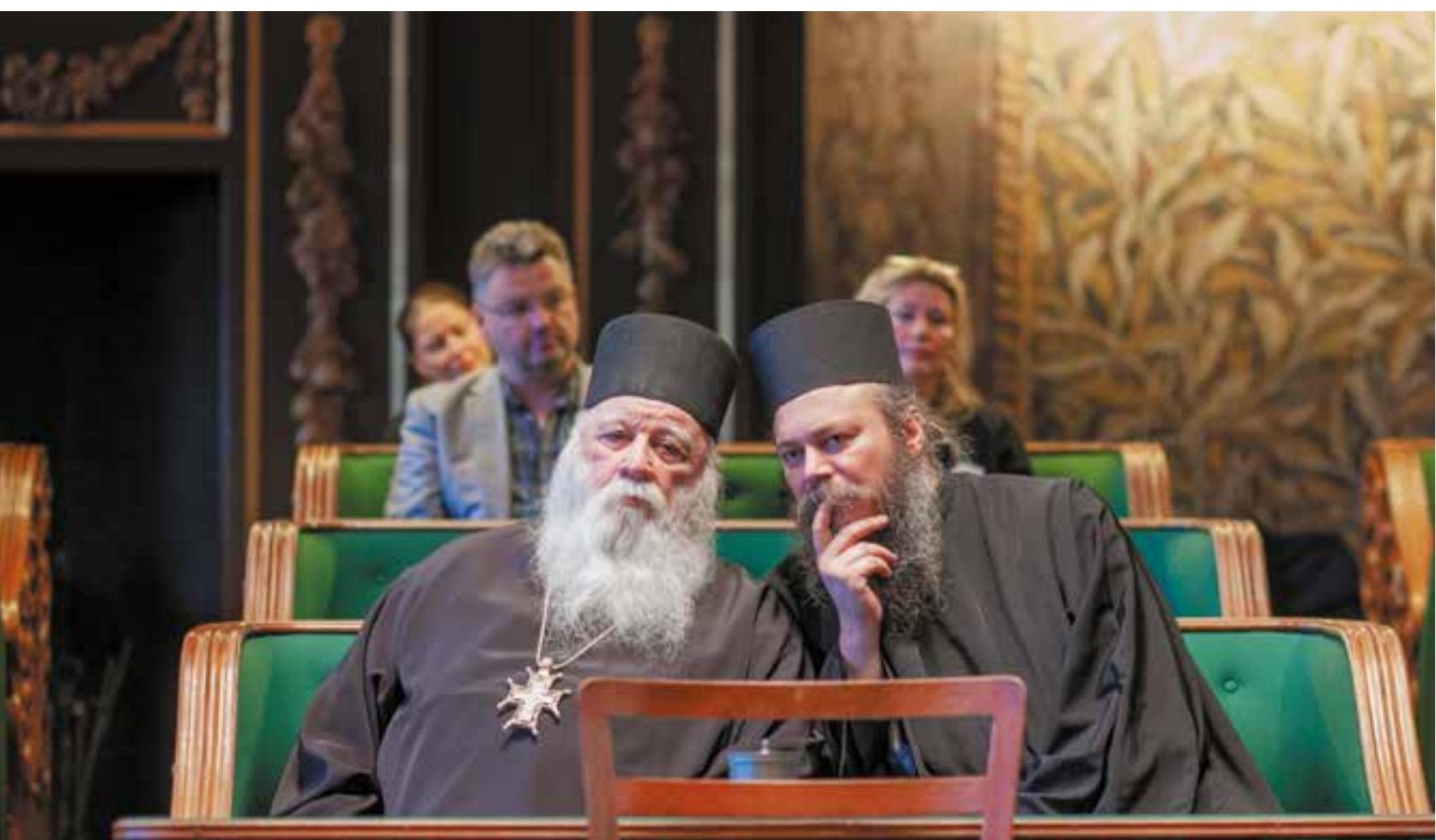




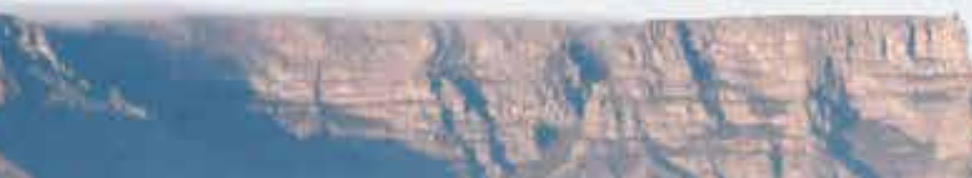
(a)

$\rightarrow+2$ ach

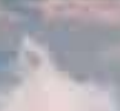

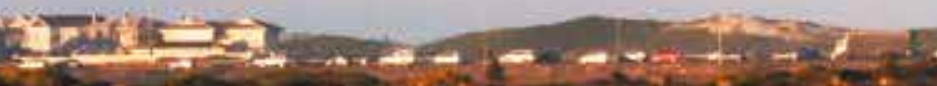
ำis

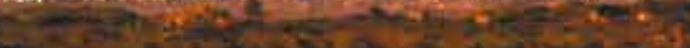
Ex

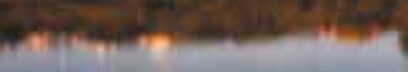

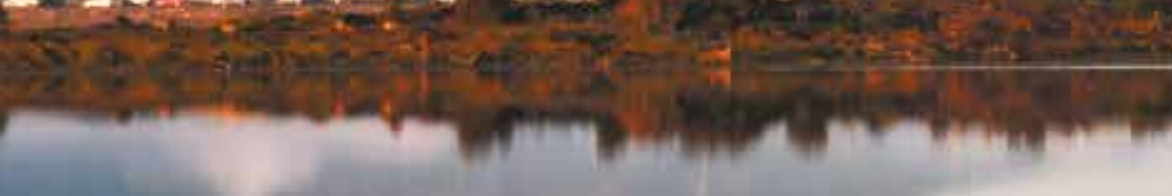
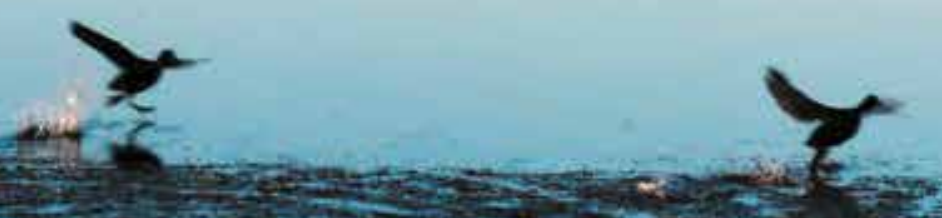

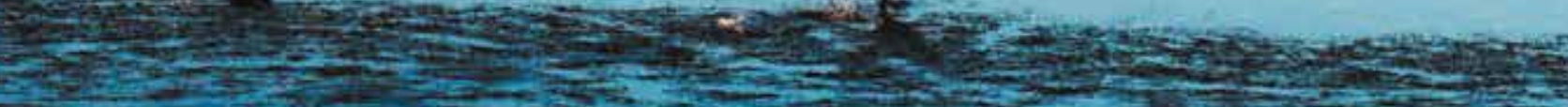
Evis

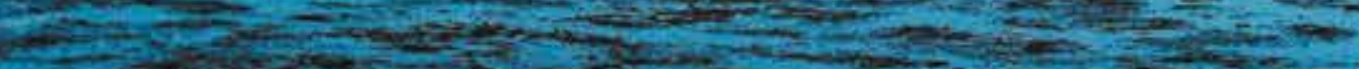

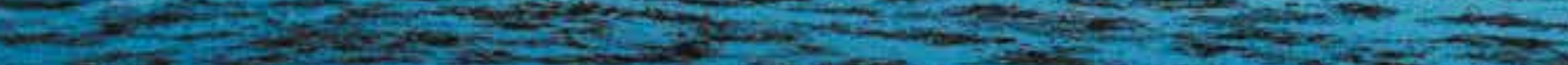
Whes

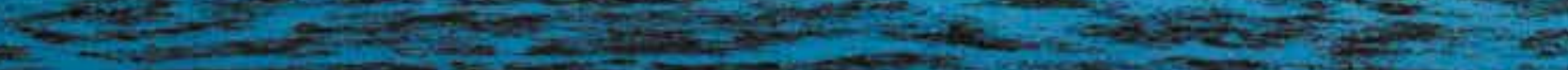

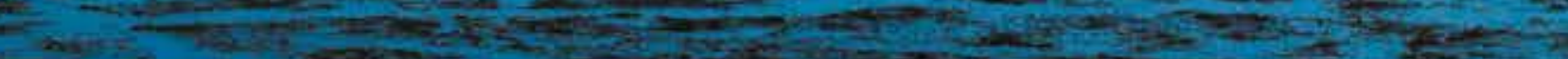

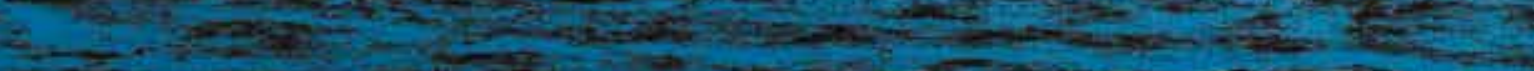

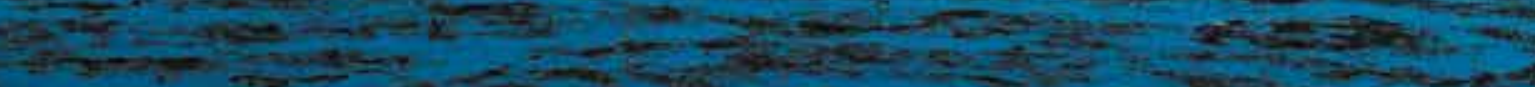
2.

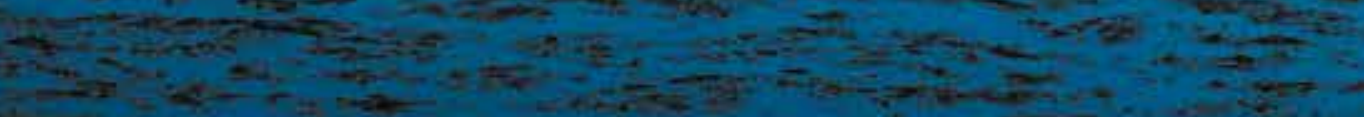


